\title{
Standarisasi Mutu Lulusan sebagai Kesiapan Mahasiswa Calon Guru Profesional pada Program Studi Pendidikan Agama Islam Fakultas Tarbiyah dan Ilmu Keguruan Universitas Islam Negeri Kiai Haji Achmad Siddiq Jember
}

\author{
Imron Fauzi ${ }^{*}$, Qurrota A'yun ${ }^{2}$ \\ ${ }^{1}$ UIN Kiai Haji Achmad Siddiq Jember \\ ${ }^{2}$ UIN Kiai Haji Achmad Siddiq Jember
}

Keywords:
Graduate Quality
Standardization, Student
Preparedness for Professional
Teacher Candidates.

*Correspondence Address: imronfauzi@uinkhas.ac.id

\begin{abstract}
This article discusses the standardization of graduate quality as the readiness of prospective professional teacher students at the Islamic Religious Education Study Program, Faculty of Tarbiyah and Teacher Training, Kiai Haji Achmad Siddiq State Islamic University Jember. This study uses a qualitative method by conducting semi-structured interviews, observation, and documentation. Sample selection using the purposive method. The findings of this study are that the standardization of graduate quality consists of 4 components: Student Quality Assistance Books, Curriculum Equivalent Books, Comprehensive Examination Quality Assistance Books, and Internal Quality Assurance Systems (SPMI). Quality standards for graduates are formulated by the Faculty Quality Assurance Team, along with the Study Program Quality Control Team, as well as lecturers. The implementation of graduate quality standards includes quality bills that must be mastered by students, namely bills for memorizing the letters of juz 30, memorizing tarbawi verses, and memorizing tarbawi traditions. The implementation obstacle encountered was the existence of the SPAN system in the student selection process which was only based on report cards, causing the mapping of the ability to read and write the Koran and religious understanding to be unclear.
\end{abstract}

\begin{abstract}
Abstrak: Artikel ini membahas tentang standarisasi mutu lulusan sebagai kesiapan mahasiswa calon guru profesional pada Program Studi Pendidikan Agama Islam Fakultas Tarbiyah dan Ilmu Keguruan Universitas Islam Negeri Kiai Haji Achmad Siddiq Jember. Penelitian ini menggunakan metode kualitatif dengan melakukan wawancara semi terstruktur, observasi, dan dokumentasi. Pemilihan sampel menggunakan metode purposive. Temuan penelitian ini yaitu standarisasi mutu lulusan terdiri ada 4 komponen: Buku Pendamping Mutu Mahasiswa, Buku Ekuivalen Kurikulum, Buku Pendamping Mutu Ujian Komprehensif, dan Sistem Penjaminan Mutu Internal (SPMI). Standar mutu lulusan dirumuskan oleh Tim Gugus Penjaminan Mutu fakultas, beserta Tim Gugus Kendali Mutu prodi, serta para dosen. Implementasi standar mutu lulusan diantaranya melalui tagihan-tagihan mutu yang harus dikuasai oleh mahasiswa yaitu tagihan hafalan surat-surat juz 30, hafalan ayatayat tarbawi, dan hafalan hadis-hadis tarbawi. Kendala implementasi yang ditemui yaitu dengan adanya sistem SPAN dalam proses seleksi mahasiswa yang hanya didasarkan nilai raport menyebabkan pemetaan kemampuan BTQ dan pemahaman keagamaan masih kurang jelas.
\end{abstract}


Standarisasi Mutu Lulusan sebagai Kesiapan Mahasiswa Calon Guru Profesional pada Program Studi Pendidikan Agama Islam Fakultas Tarbiyah dan Ilmu Keguruan Universitas Islam Negeri Kiai Haji Achmad Siddiq Jember | Imron Fauzi, Qurrota A'yun

\section{PENDAHULUAN}

Pendidikan Agama Islam sebagai suatu proses ikhtiyariyah mengandung ciri dan watak khusus, yaitu proses penanaman, pengembangan dan pemantapan nilai-nilai keimanan yang menjadi fundamen mentalspritual manusia dimana sikap dan tingkah lakunya termanifestasikan menurut kaidahkaidah agamanya. Nilai-nilai keimanan seseorang adalah keseluruhan pribadi yangmenyatakan diri dalam bentuk tingkah laku lahiriah dan rohaniah, dan ia merupakan tenaga pendorong yang fundamental, bagi tingkah laku seseorang. Pendidikan Islam juga melatih kepekaan (sensibility) para peserta didik sedemikian rupa, sehingga sikap hidup dan prilaku didominasi oleh perasaan mendalam nilai-nilai etis dan spritual Islam. Mereka dilatih, sehingga mencari pengetahuan tidak sekedar untuk memuaskan keingintahuan intelelektual atau hanya untuk keuntungan dunia material belaka, tetapi juga untuk mengembangkan diri sebagai makhluk rasional dan saleh yang kelak akan memberikan kesejahteraan fisik, moral dan spritual bagi keluarga, masyarakat dan umat manusia. Pandangan ini berasal dari keimanan mendalam kepada Allah. ${ }^{1}$

Guru merupakan suatu profesi, yang berarti suatu jabatan yang memerlukan keahlian khusus sebagai guru dan tidak dapat dilakukan oleh sembarang orang diluar bidang pendidikan. Orang yang pandai berbicara dalam bidang-bidang tertentu, belum dapat disebut sebagai guru. Untuk menjadi guru diperlukan

1 Abdullah Syahid, Penerapan Pembelajaran Pendidikan Agama Islam Dalam Membentuk Karakter Pribadi yang Islami, Jurnal Edumaspul, Vol. 2 N0. 1, 2018, 2. syarat-syarat khusus, apalagi sebagai guru yang profesioanal yang harus menguasai betul seluk beluk pendidikan dan pengajaran dengan berbagai ilmu pengetahuan lainnya yang perlu dibina dan dikembangkan melalui masa pendidikan tertentu atau pendidikan prajabatan. ${ }^{2}$

Pendidikan merupakan suatu kegiatan yang universal dalam kehidupan manusia. Pendidikan merupakan gejala umum dalam kehidupan masyarakat, namun perbedaan pandangan hidup, perbedaan falsafah hidup yang dianut oleh masing-masing bangsa atau masyarakat menyebabkan adanya perbedaan penyelenggaraan termasuk perbedaan tujuan pendidikan yang ingin dicapai oleh suatu bangsa atau masyarakat. ${ }^{3}$

Pendidikan yang telah diatur dan didefinisikan dalam Undang-undang Sistem Pendidikan Nasional (UU Sisdiknas) Nomor 20 tahun 2003. Dalam UU tersebut bahwa: "pendidikan didefinisikan sebagai usaha sadar dan terencana untuk mewujudkan suasana belajar dan proses pendidikan agar peserta didik secara aktif mengembangkan potensi dirinya untuk memiliki kekuatan spiritual keagamaan, pengendalian diri, kepribadian, kecerdasan, akhlak mulia, serta keterampilan yang diperlukan dirinya, masyarakat, bangsa dan negara".4

Pendidikan dapat diartikan sebagai bimbingan secara sadar oleh

2 Sumiatini, Peran Guru Kelas Dalam Meningkatkan Motivasi Belajar Siswa, Jurnal Tarbawi, Vol. 3 N0. 02, 2016, 15.

3 Uyoh Sadulloh, Pedagogik (Ilmu Mendidik), (Bandung: Alfabeta, 2010), 72.

4 Husaini Usman, Manajemen Teori, praktik, riset pendidikan, (Jakarta: Bumi Aksara, 2009), 11 
pendidik terhadap perkembangan jasmani dan rohani peserta didik menuju terbentuknya kepribadian yang utama. Sehingga pendidikan dipandang sebagai salah satu aspek yang memiliki peranan pokok dalam membentuk generasi muda agar memiliki kepribadian yang utama. ${ }^{5}$

Permasalahan akademik yang ditemuan saat observasi awal ialah masih banyak mahasiswa yang kesulitan Baca Tulis Al-Qur'an (BTQ) dan tingkat pemahaman keagaman yang rendah. Namun sayangnya, karena diberlakukannya sistem Daring untuk seluruh kegiatan akademik termasuk perwalian mahasiswa sampai waktu yang tidak menentu, sehingga Buku Pendamping Mutu Mahasiswa sebagai kendali mutu akademik ini yang seharusnya bisa membantu akan standart mutu mahasiswa, dikarenakan mahasiswa tidak bisa interaksi langsung dengan DPA yang tugasnya mengontrol akan standart mutu mahasiswa itu sendiri.

Keunikan dari standarisasi mutu lulusan pada mahasiswa PAI sebagai calon guru professional Buku pendamping mutu mahasiswa, didalam buku tersebut terdapat tagihan tagihan mutu, yaitu tagihan hafalan surat-surat pendek juz 30, hafalan ayat-ayat tarbawi/kependidikan, dan hafalan tentang hadits tarbawi, Buku Ekuivalen Kurikulum FTIK, Buku Pendamping Mutu Ujian, dan telah memiliki dokumen SPMI.

5 Nur Kholis, Pendidikan Dalam Upaya Memajukan Teknologi, Jurnal Kependidikan, Vol. 1 No. 1, 24.

\section{KAJIAN TEORI \\ Standarisasi Mutu Lulusan}

Standarisasi adalah menentukan ukuran yang harus diikuti saat memproduksi produk tertentu, dan untuk menghasilkan produk yang akan diproduksi dalam berbagai ukuran merupakan tugas yang disederhanakan. ${ }^{6}$ Standarisasi adalah proses penetapan standar teknis, yang dapat berupa spesifikasi standar, standar metode pengujian, standar definisi, prosedur standar atau praktik.

Mutu berarti kepuasan pelanggan. Dengan demikian, setiap bagian proses dalam organisasi memiliki pelanggan. Kepuasan pelanggan internal akan menyebabkan kepuasan pelanggan organisasi. Juran berpendapat bahwa mutu berarti kesesuaian dengan penggunaan, seperti sepatu yang dirancang untuk olahraga atau sepatu kulit yang dirancang untuk ke kantor. Pendekatan Juran adalah orientasi pada pemenuhan harapan pelanggan. Mutu merupakan derajat/tingkat karakteristik yang melekat pada produk yang mencukupi persyaratan / keinginan. Maksud derajat / tingkat berarti selalu ada peningkatan setiap saat. Sedangkan karakteristik berarti hal-hal yang dimiliki produk, yang terdiri dari karakteristik fisik, karakteristik perilaku dan karakteristik sensori. ${ }^{7}$

Lulusan sebagai output merupakan bagian dari sistem dalam manajemen mutu Pendidikan. mutu lulusan tidak dapat dipisahkan dari contect, input, proses, output dan

\footnotetext{
6 Putu Subawa, Standarisasi Dunia Pendidikan, Jurnal Penjaminan Mutu Vol 02 No 02, 2016, 3.

7 Sri Winarsih, Kebijakan dan Implementasi Manajemen Pendidikan Tinggi dalam Meningkatkan Mutu Pendidikan, Cendekia, Vol. 15 No. 1, 2017, 53.
} 
outcome. Untuk itu, mutu lulusan yang sesuai dengan keinginan pelanggan Pendidikan adalah output yang mempunyai kriteria sebagai outcome yaitu dapat melanjutkan ke sekolah yang lebih tinggi dan siap untuk bekerja. Atau bisa dikatakan lulusan yang sesuai dengan Standar Kompetensi Lulusan (SKL) satuan Pendidikan, yaitu kualifikasi kemampuan lulusan yang mencakup pengetahuan, keterampilan, dan sikap, yang digunakan sebagai pedoman penilaian dalam penentuan kelulusan peserta didik dari satuan Pendidikan. SKL pada jenjang Pendidikan bertujuan untuk meningkatkan kecerdasan, pengetahuan, kepribadian, akhlak mulia, serta keterampilan untuk hidup mandiri dan mengikuti Pendidikan lebih lanjut. ${ }^{8}$

Perguruan tinggi memiliki keleluasaan mengatur pemenuhan Standar Nasional Pendidikan Tinggi, dimana menteri melakukan evaluasi terhadap pelaksanaan standar pendidikan tinggi secara berkala. Terkait dengan itu, pentingnya standar mutu pendidikan tinggi untuk setiap satuan pendidikan. Pentingnya standar mutu pendidikan tinggiitu dilakukan dalam sejumlah aspek yang disebut butir-butir mutu:

1. Sebagai acuan dasar dalam rangka mewujudkan visi dan menjalankan misi;

2. Untuk memacu pendidikan tinggi agar dapat meningkatkan kinerjanya dalam memberikan layanan yang bermutu dan sebagai perangkat untuk mendorong terwujudnya transparansi dan akuntabilitas publik dalam penyelenggaraan tugas pokoknya;

8 Mulyasa, Kurikulum Tingkat Satuan Pendidikan (Bandung: Remaja Rosdakarya, 2012), 91.
3. Sebagai kompetensi/ kualitas minimum yang dituntut dari lulusan pendidikan tinggi, yang dapat diukur dan dapat diuraikan menjadi parameter dan indikator. ${ }^{9}$

Standar mutu lulusan mahasiswa dapat disimpulkan bahwa standarisasi mutu lulusan adalah standar mutu kelulusan yang dibentuk untuk mengukur hasil kemampuan mahasiswa, ukuran yang digunakan sebagai dasar untuk membandingkan kuantitas, kualitas dengan perumusan standar mutu mahasiswa yang meliputi standar mutu akademik dan non akademik, diamana standar mutu itu dirumuskan dengan melibatkan semua objek yang ada dalam perguruan tinggi tersebut.

\section{Kesiapan Mahasiswa}

Kesiapan mahasiswa adalah seseorang yang sedang dalam proses menimba ilmu ataupun belajar dan terdaftar sedang menjalani pendidikan pada salah satu bentuk perguruan tinggi di suatu kondisi yang dimiliki baik seseorang/individu dalam mempersiapkan diri baik secara fisik maupun mental untuk mencapai tujuan yang dikehendaki setelah diberikan atau dibekali baik pengajaran maupun latihan-latihan yang sesuai. Kesiapan menghadapi dunia kerja sangat dibutuhkan setelah mempunyai bekal yang cukup agar bisa secara optimal meluangkan tenaga dan pikirannya dalam pekerjaan tersebut. ${ }^{10}$

Kesiapan mahasiswa yang perlu disiapkan sebagai guru profesional dalam bidang kompetensinya ada 4

\footnotetext{
9 Universitas Sriwijaya, Standar Mutu, (Ogan Ilir: UPM Usri), 5.

10Wagiran, Kesiapan Mahasiswa Dalam Implementasi Pembelajaran Aktif Kontruktif, Jurnal Kependidikan, Vol. 35, No. 1, 20.
} 
meliputi: Pertama, kompetensi paedagogik yaitu suatu kemampuan yang dimiliki mahasiswa sebagai calon guru dalam mengelola pembelajaran, evaluasi hasil belajar, perancangan dan pelaksanaan pembelajaran. Kedua, kompetensi profesional yaitu mahasiswa mampu menguasai materi pembelajaran secara luas dan mendalam yang mencakup penguasaan materi kurikulum mata pelajaran di sekolah dan substansi keilmuan yang menaungi materinya, serta penguasaan terhadap struktur dan metodologi keilmuan. Ketiga kompetensi sosial, yaitu mahasiswa mampu menunjukkan atau mampu berinteraksi sosial, baik dengan sesama mahasiswa maupun dengan sesama dosen, bahkan masyarakat luas. Keempat kompetensi kepribadian, yaitu seorang mahasiswa sebagai calon guru memiliki sikap kepribadian yang stabil, dewasa, arif, bijaksana, berwibawa, berakhlak mulia dan dapat menjadi tauladan bagi peserta didik. ${ }^{11}$

Mahasiswa adalah seseorang yang sedang dalam proses menimba ilmu ataupun belajar dan terdaftar sedang menjalani pendidikan pada salah satu bentuk perguruan tinggi yang terdiri dari akademik, politeknik, sekolah tinggi, institut dan universitas. ${ }^{12}$

1. Aspek-aspek Kesiapan Mahasiswa

Kondisi kesiapan Mahasiswa mencakup 3 (tiga) aspek, diantaranya adalah: a) Kondisi fisik, mental dan emosional. b) Kebutuhan-kebutuhan, motif dan tujuan. c) Keterampilan, pengetahuan dan pengertian yang lain yang telah dipelajari. ${ }^{13}$

11 Imron Fauzi, Etika Profesi Keguruan (Jember: IAIN Jember Pers, 2019), 145

12 Hartaji, Motiva berprestasi pada mahasiswa (Depok: Gunadarmapers, 2012), 15.

13 Edy Sutrisno, Manajemen Sumber Daya Manusia, (Jakarta: Kencana, 2009), 115 a. Kesiapan fisik dan psikis

Guru juga dituntut untuk memiliki fisik dan mental yang sehat. Fisik yang sehat berarti terhindar dari berbagai macam penyakit. Guru yang sakit bukan saja tidak mungkin dapat melaksanakan tugas dengan baik, tetapi juga kemungkinan besar akan menularkan penyakitnya kepada anakanak. Kesehatan mental berarti guru terhindar dari berbagai bentuk gangguan dan menyangga mental. Gangguan-gangguan mental yang diderita guru dapat mengganggu bahkan merusakkan interaksi pendidikan. Guru yang mengalami gangguan mental tidak mungkin mampu menciptakan hubungan yang hangat, bersahabat, penuh kasih sayang, penuh pengertian dengan para siswanya. Kesehatan fisik dan mental mutlak diperlukan dari orang-orang yang bekerja sebagai guru.

b. Kematangan/kedewasaan untuk melakukan sesuatu

Sebagai pribadi, pengajar, pendidik dan pembimbing dituntut memiliki kematangan atau kepribadian yang dewasa. Minimal ada 3 (tiga) ciri kematangan/kedewasaan yaitu: Pertama, orang yang telah dewasa memiliki tujuan dan pedoman hidup (philosophy of life). Seseorang yang telah dewasa tidak mudah terombang ambing karena telah punya pegangan yang jelas, kemana akan pergi, dan dengan cara mana untuk mencapainya. Kedua, orang yang telah dewasa mampu melihat segala sesuatu secara objektif. Tidak dipengaruhi oleh subjektivitas dirinya, lebih dari itu ia mampu bertindak sesuai dengan hasil penglihatan tersebut. Ketiga Orang yang telah dewasa mampu bertanggung jawab. Orang dewasa adalah orang yang memiliki kebebasan, tetapi disisi lain kebebasan 
adalah sebuah tenggung jawab. Dia bebas menentukan arah hidupnya, perbuatannya, tetapi setelah berbuat ia dituntut untuk bertanggung jawab. Guru harus terdiri atas orang-orang yang bisa bertanggung jawab atas segala perbuatannya. Perbuatan yang bertanggung jawab adalah perbuatan yang berencana, yang dikaji terlebih dahulu sebelum dilakukan.
c. Penguasaan pengetahuan dan kecakapan

Selain harus memenuhi syaratsyarat kematangan, sehat jasmani dan rohani, guru juga harus memiliki ilmu dan kecakapan serta keterampilan keguruan. Ilmu dan kecakapan keterampilan tersebut diperoleh selama menempuh pelajaran di lembaga pendidikan keguruan. Agar mampu menyajikan dan menyampaikan ilmu pengetahuan atau bidang studi yang diajarkannya dengan baik, ia harus menguasai ilmu atau bidang tersebut secara mendalam dan meluas. Guru juga dituntut untuk menguasai strategi atau metode mengajar yang baik. Ia diharapkan dapat mempersiapkan pengajaran, melaksanakan dan menilai hasil belajar para siswa dengan baik. Dapat memilih dan menggunakan modelmodel interaksi belajar-mengajar yang tepat, mengelola kelas dan membimbing perkembangan siswa dengan tepat.

2. Faktor-faktor yang mempengaruhi kesiapan

Kesiapan sesorang dalam menjadi guru ditentukan oleh kemampuan dalam menguasai bidangnya, minat, bakat, keselarasan dengan tujuan yang ingin dicapai dan sikap terhadap bidang profesinya. Tekad, semangat dan lingkungan keluarga juga tidak terlepas dari faktor pendukung kesiapan menjadi guru.
Menurut Wasti Soemanto, kesiapan (readness) adalah kesediaan seseorang untuk berbuat sesuatu yang selanjutnya dapat dituangkan menjadi prinsip-prinsip kesiapan, meliputi: ${ }^{14}$
a. Semua aspek perkembangan interaksi.
b. Pengalaman mempengaruhi
seseorang
fisiologis individu.
c. Pengalaman-pengalaman mempunyai efek komulatif dalam perkembangan funsi kepribadian individu, baik jasmani maupun rohani.
d. Kesiapan dasar untuk kegiatan tertentu terbentuk pada diri seseorang merupakan masa perkembangan pribadi.
Kesiapan ialah kematangan dan pertumbuhan fisik, psikis, intelegensi, latar belakang pengalaman, motivasi, persepsi, dan faktor-faktor lain yang memungkinkan seseorang dapat melakukan sesuatu. Dari uraian di atas dapat disimpulkan bahwa kesiapan menjadi guru dipengaruhi oleh beberapa faktor yaitu fakor fisiologis, faktor psikologis dan faktor pengalaman individu dan sesuai dengan yang akan diteliti tentang perumusan, implementasi dan ketercapaian standar mutu lulusan pada mahasiswa program studi PAI sebagai calon guru professional.

\section{Guru Profesional}

Dalam pasal 1 Undang-Undang No. 14 tahun 2005 tentang guru dan dosen disebutkan bahwa "Guru adalah pendidik professional dengan tugas utama mendidik, mengajar, membimbing, mengarahkan, melatih, menilai dan mengevaluasi peserta

14 Wasty Soemanto, Psikologi Pendidikan, (Jakarta: PT. Rhineka Cipta, 2006), 191-192. 
didik pada pendidikan usia dini jalur pendidikan formal, pendidikan dasar, dan pendidikan menengah. ${ }^{15}$

Guru merupakan suatu profesi. Suatu profesi erat kaitannya dengan jabatan atau pekerjaan tertentu yang dengan sendirinya menuntut keahlian, pengetahuan, dan keterampilan tertentu pula. Dalam pengertian profesi telah tersirat adanya suatu keharusan kompetensi agar profesi itu berfungsi dengan sebaik-baiknya. Dalam hal ini, pekerjaan profesional berbeda dengan pekerjaan-pekerjaan lainnya. Oleh sebab mempunyai fungsi sosial, yakni pengabdian kepada masyarakat. 16

Guru merupakan salah satu faktor penting dalam proses pembelajaran. Bagaimanapun idealnya suatu kurikulum tanpa ditunjang oleh kemampuan guru untuk mengimplementasikannya maka kurikulum itu tidak akan bermakna sebagai suatu alat pendidikan. ${ }^{17}$

Seorang guru memiliki tugas yang harus dikerjakan meliputi mendidik, mengajar, melatih, menjadi orangtua kedua di sekolah, serta mencerdaskan bangsa dan ikut menciptakan dan membentuk warga masyarakat yang bermoral Pancasila.

\section{Kompetensi sebagai Calon Guru Profesional \\ Sebagai \\ calon guru guru profesional dalam bidang kompetensinya ada 4 meliputi:}

\footnotetext{
${ }^{15}$ Anggota IKAPI, Undang-Undang No. 14 tahun 2005 tentang Guru dan Dosen, Bab 1, Pasal 1, Ayat 1, (Bandung: Fokusmedia, 2011), 2

16 Oemar Hamalik, Pendidikan Guru Berdasarkan Pendekatan Kompetensi, (Jakarta: PT Bumi Aksara,2007), 3.

17 Abd. Rahman Getteng, Menuju Guru Profesional dan Beretika, (Yogyakarta: Grha Guru, 2012), 8
}

1. Kompetensi Paedagogik

Kompetensi Paedagogik adalah suatu kemampuan yang dimiliki mahasiswa sebagai calon guru dalam mengelola pembelajaran, evaluasi hasil belajar, perancangan dan pelaksanaan pembelajaran. ${ }^{18}$

Dalam Permendiknas No.16/2007 tentang Standar Kualifikasi Akademik dan Kompetensi Guru meliputi: (1) Menguasai karakteristik peserta didik dari aspek fisik, moral, spiritual, sosial, kultural, emosional, dan intelektual; (2) Menguasai teori belajar dan prinsip-prinsip pembelajaran yang mendidik; (3) Mengembangkan kurikulum yang terkait dengan mata pelajaran yang diampu; Menyelenggarakan pembelajaran yang mendidik; (5) Memanfaatkan teknologi informasi dan komunikasi untuk kepentingan pembelajaran; (6) Memfasilitasi pengembangan potensi peserta didik untuk mengaktualisasikan berbagai potensi yang dimiliki; (7) Berkomunikasi secara efektif, empatik, dan santun dengan peserta didik; (8) Menyelenggarakan penilaian dan evaluasi proses dan hasil belajar; (9) Memanfaatkan hasil penilaian dan evaluasi untuk kepentingan pembelajaran; (10) Melakukan tindakan reflektif untuk peningkatan kualitas pembelajaran.

2. Kompetensi profesional

Kompetensi profesional adalah mahasiswa mampu menguasai materi pembelajaran secara luas dan mendalam yang mencakup penguasaan materi kurikulum mata pelajaran di sekolah dan substansi keilmuan yang menaungi materinya, serta penguasaan

18 Fauzi, 145. 
terhadap struktur dan metodologi keilmuan, yang ketiga. ${ }^{19}$

Dalam Permendiknas No.16/2007 tentang Standar Kualifikasi Akademik dan Kompetensi Guru meliputi: (1) Menguasai materi, struktur, konsep, dan pola pikir keilmuan yang mendukung mata pelajaran yang diampu; (2) Menguasai standar kompetensi dan kompetensi dasar mata pelajaran yang diampu; (3) Mengembangkan materi pembelajaran yang diampu secara kreatif; (4) Mengembangkan keprofesionalan secara berkelanjutan dengan melakukan refleksi; (5) Memanfaatkan teknologi informasi dan komunikasi untuk mengembangkan diri.

3. Kompetensi sosial

Kompetensi sosial yaitu mampu menunjukkan atau mampu berinteraksi sosial, baik dengan sesama mahasiswa maupun dengan sesama dosen, bahkan masyarakat luas. ${ }^{20}$

Dalam Permendiknas No.16/2007 tentang Standar Kualifikasi Akademik dan Kompetensi Guru meliputi: (1) Bersikap inklusif, bertindak objektif, serta tidak diskriminatif karena pertimbangan jenis kelamin, agama, ras, kondisi fisik, latar belakang keluarga, dan status sosial ekonomi; (2) Berkomunikasi secara efektif, empatik, dan santun dengan sesama pendidik, tenaga kependidikan, orang tua, dan masyarakat; (3) Beradaptasi di tempat bertugas di seluruh wilayah Republik Indonesia yang memiliki keragaman sosial budaya; (4) Berkomunikasi dengan komunitas profesi sendiri dan profesi lain secara lisan dan tulisan atau bentuk lain.

4. Kompetensi kepribadian,
Kompetensi kepribadian yaitu seorang mahasiswa sebagai calon guru memiliki sikap kepribadian yang stabil, dewasa, arif, bijaksana, berwibawa, berakhlak mulia dan dapat menjadi tauladan bagi peserta didik. ${ }^{21}$

Dalam Permendiknas No.16/2007 tentang Standar Kualifikasi Akademik dan Kompetensi Guru meliputi: (1) Bertindak sesuai dengan norma agama, hukum, sosial, dan kebudayaan nasional Indonesia; (2) Menampilkan diri sebagai pribadi yang jujur, berakhlak mulia, dan teladan bagi peserta didik dan masyarakat; (3) Menampilkan diri sebagai pribadi yang mantap, stabil, dewasa, arif, dan berwibawa; (4) Menunjukkan etos kerja, tanggung jawab yang tinggi, rasa bangga menjadi guru, dan rasa percaya diri; (5) Menjunjung tinggi kode etik profesi guru.

Selain 4 kompetensi diatas, guru juga harus memiliki 11 sifat yaitu: Pertama, ikhlas yaitu seorang guru harus menanamkan sifat ikhlas ke dalam jiwa murid-muridnya. Kedua, Jujur adalah penyelamat bagi guru di dunia dan akhirat. Bohong kepada murid akan menghalangi penerimaan dan menghilangkan kepercayaan. Ketiga, walk the walk yaitu adanya perbedaan ucapan dengan perilaku seorang guru hanya akan membuat seorang murid berada dalam kebingungan. Keempat, adil yaitu Allah memerintahkan untuk bersikap adil dan mewajibkan hamba-Nya untuk berlaku adil terhadap kerabat dekat ataupun jauh, juga terhadap musuh sekalipun. Kelima, akhlak mulia yaitu Akhlak adalah sikap yang terpuji yang harus dimiliki oleh seorang guru. Keenam, tawadhu yaitu Dampak dari sifat tawadhu bukan hanya dirasakan

${ }^{21}$ Fauzi, 149.

${ }^{19}$ Fauzi, 151.

${ }^{20}$ Fauzi, 152. 
oleh seorang guru, tetapi juga akan dirasakan oleh para murid. Ketujuh, yaitu berani sifat berani adalah tuntutan yang seharusnya dipenuhi oleh setiap guru. Kedelapan, mempunyai humor yang tinggi yaitu terciptanya suasana nyaman di ruang kelas, halaqah, atau pertemuan tertentu. Kesembilan, sabar adalah alat yang paling baik bagi kesuksesan seorang guru. Kesepuluh, menjaga lisan. Kesebelas, sinergin dan bermusyawarah dengan artian Bermusyawarah dapat membantu seorang guru dalam menghadapi suatu permasalahan atau perkara sulit yang dihadapinya. ${ }^{22}$

\section{Fakultas Tarbiyah dan Ilmu Keguruan Universitas Islam Negeri Kiai Haji Achmad Siddiq Jember}

Fakultas Tarbiyah dan Ilmu Keguruan (FTIK) Universitas Islam Negeri Kiai Haji Achmad Siddiq (KHAS) Jember adalah salah satu fakultas yang memiliki anggota mahasiswa terbanyak dibandingkan dari fakultasfakultas lainnya. FTIK sebagai bagian integral UIN KHAS Jember, merumuskan visi untuk mendukung dan mempercepat pencapaian visi UIN KHAS Jember. Sebagaimana terdeskripsikan pada Renstra FTIK Tahun 2019-2022, visi FTIK yaitu "Menjadi Pencetak Tenaga Pendidik dan Kependidikan yang unggul, berintegrasi, professional dan kompetitif berbasis nilai-nilai Islam Nusantara". ${ }^{23}$

FTIK ini mengelola 11 Program Studi, salah satunya adalah program studi Pendidikan Agama Islam. Mahasiswa Pendidikan Pendidikan

\footnotetext{
22 Fauzi, 69

23 IAIN Jember, "Buku Panduan PPL" 11 Juni 2021.
}

Agama Islam (PAI) adalah mahasiswa yang disiapkan untuk menjadi calon guru bagi siswa di sekolah. Sebagai calon guru, mahasiswa harus memiliki bekal pengetahuan dan keahlian yang cukup. Bekal tersebut diperlukan calon guru agar siap menjadi guru yang dapat menyalurkan pengetahuan dan nilai serta dapat memberikan tauladan yang baik bagi peserta didik. ${ }^{24}$

Keunikan standar mutu FTIK dibanding fakultas lain. Beberapa produk standar mutu FTIK meliputi: (1) Buku Pendamping Mutu Mahasiswa, sebagai pengendalian mutu akademik melalui pendampingan konsultasi dengan DPA. Adapun tugas Dosen atau DPA yaitu: (a) Mengarahkan mahasiswa dalam memilih mata kuliah yang akan diambil pada setiap permulaan semester, (b) Memberikan pertimbangan kepada mahasiswa tentang beban kredit yang akan diambil, (c) Menyetujui dan menandatangani KRS mahasiswa bimbingannya, (d) Membantu mahasiswa dalam melaksanakan caracara belajar efektif dan efisien di Perguruan Tinggi, (e) Membantu mahasiswa dalam memahami dan menghayati tradisi kerja dan sikap ilmiah di Perguruan Tinggi, (f) Membantu mahasiswa dalam memecahkan masalah yang dapat mengganggu kelancaran studinya., (g) Memantau perkembangan studi mahasiswa terutama mahasiswa yang terancam putus studi atau drop-out (DO), (h) Membina akhlak mulia mahasiswa dalam kebiasaan hidupnya. ${ }^{25}$ Di dalam buku tersebut

24 IAIN Jember, "Buku Panduan PPL" 11 Juni 2021

25 Deasy Yunika Khairun, Ibrahim Al Hakim, "Analisis Asesmen Kebutuhan Mahasiswa Terhadap Layanan Dosen Pembimbing 
terdapat tagihan tagihan, Mutu: Pertama, tagihan hafalan surat-surat pendek juz 30; Kedua, hafalan ayatayat tarbawi/kependidikan; Ketiga, hafalan tentang hadits tarbawi. Seluruh tagihan mutu tersebut dihafalkan secara berangsur-angsur sesuai dengan sceedule yang sudah terjadwal seperti buku didalam buku tersebut. (2) Buku ekuivalen kurikulum FTIK, didalamnya berisi seluruh sebaran mata kuliah di setiap program studi FTIK. Fungsi buku ini yang paling utama yaitu mempermudah mahasiswa dalam menempuh mata kuliah baik program bawah maupun program atas, yang pernah tertinggal pada semester berikutnya mau ditempuh di semester ternyata mata kuliah tersebut sudah tidak ada, maka bisa dilihat dari buku ekuivalen tersebut; (3) Buku Pendamping Mutu Ujian Komprehensif, didalam buku ini meliputi mekanisme terkait mengenai ujian komprehensif, materi pelaksanaan penilaian dan kisi-kisi ujian komprehensif; (4) Sistem Penjaminan Mutu Internal (SPMI) FTIK, yang didalamya terdapat 4 dokumen yang meliputi: dokumen kebijakan mutu, dokumen manual mutu, dokumen standar mutu dan dokumen formulir mutu, SPMI ini ibaratkan jantungnya pelaksanaan mutu di fakultas dan seluruh pelaksanaan dan pengembangan mutu baik akademik maupun non-akademik menjadi terarah dan sistematis.

\section{METODE PENELITIAN}

Penelitian ini menggunakan
metode kualitatif dengan sesi
wawancara. Metode ini dipilih karena

Akademik", Jurnal Indonesia Konseling Pendidikan, Vol. 2 No. 2, 2018, 38 peneliti dapat mengenali perasaan orang yang diwawancarai dan menghargai pengalaman individu dalam masyarakat. ${ }^{26}$ Selain itu, untuk mencapai tujuan penelitian ini, pendekatan kualitatif dipandang lebih cocok untuk memahami suatu fenomena secara mendalam, seperti Berdasarkan pandangan Creswell bahwa metode kualitatif lebih cocok untuk eksplorasi suatu fenomena

Lokasi yang dipilih dalam penelitian ini adalah Kampus Institut Agama Islam Negeri Jember yang terletak di Jl. Mataram No 1, Karang Miujo, Mangli, Kecamatan Kaliwates, Kabupaten Jember, Jawa Timur.

Teknik pengumpulan data menggunakan observasi nonpartisipan, wawancara semi terstruktur, dan dokumenter berarti upaya pengumpulan data dengan menyelidiki benda-benda tertulis. ${ }^{27}$

Analisis data menggunakan analisis deskriptif kualitatif dengan model interaktif deskriptif Miles, Huberman dan Saldana yaitu kondensasi data, penyajian data, dan pengambilan kesimpulan. ${ }^{28}$

Keabsahan data menggunakan triangulasi sumber dan triangulasi teknik. Triangulasi sumber dilakukan dengan cara mengecek informasi atau data yang diperoleh melalui wawancara dengan informan. Kemudian data tersebut ditanyakan kepada informan lain.

26 Lexy J. Moleong, Metodelogi Penelitian Kualitatif (Bandung: PT Remaja Rosdakarya, 2017), 4.

27 Mundir, Metode Penelitian Kualitatif dan Kuantitatif (Jember, STAIN Jember Press, 2013), hal. 186

${ }^{28}$ Miles, Hubberman, Saldana Qualitative Data Analysis, A Methods Sourcebook, Edition 3 (USA: Sage Publications, 2014), 14. Terjemahan Tjetjep Rohindi Rohidi, UI-Press 


\section{HASIL DAN PEMBAHASAN}

\section{Perumusan Standarisasi Mutu Lulusan FTIK}

Perumusan standar mutu secara umum dari fakultas Gugus Penjamin Mutu dimana yang meliputi seluruh prodi, kendali mutu lingkupnya mencakup lebih kecil yaitu di masingmasing prodi itu sendiri yang ada di dalamnya, Lembaga Penjaminan Mutu dilingkup lebih besar yaitu tingkat Institut, dan meliputi dosen yang ahli dalam bidangnya dan sangat penting sekali, kompetensi yang akan dicapai nantinya oleh mahasiswa terhadap kriteria-kriteria yang harus dikuasai oleh mahasiswa di bidang tertentu.

Perumusan langkah-langkah standar mutu dalam membentuk standarisasi mutu lulusan pada mahasiswa PAI sebagai calon guru professional langkah-langkahnya pertama standar mutu itu dibentuk berdasarkan analisis lingkungan, kedua pembentukan tim standar mutu dan melibatkan tim Gugus Penjamin Mutu (GPM), kaprodi bersama tim yang lainnya termasuk dosen yang ahli dibidang ahlinya, ketiga rapat persamaan presepsi, keempat perumusan dan penyusunan standar mutu, dan selanjutnya kalau sudah final dan melalui tahap beberapa revisi bisa diterapkan ke seluruh mahasiswa.

Bentuk standarisasi mutu lulusan pada mahasiswa PAI sebagai calon guru professional Buku pendamping mutu mahasiswa, didalam buku tersebut terdapat tagihan tagihan, yang pertama tagihan hafalan suratsurat pendek juz 30, hafalan ayat-ayat tarbawi/kependidikan, yang ketiga hafalan tentang hadits tarbawi, . Buku ekuivalen kurikulum FTIK, , Buku pendamping mutu ujian komprehensif isinya tentang komprehensif, SPMI tersebut ada 4 Jenis dokumen di dalamnya: 1)Dokumen kebijakan mutu, 2)Dokumen manual mutu, 3)Dokumen standar mutu. 4)Dokumen formulir mutu.

Perumusan standar mutu yang dibentuk untuk mahasiswa ada tim dan dirumuskan bersama-sama Gugus Kendali Mutu tingkat fakultas FTIK, Gugus Kendali Mutu tingkat prodi FTIK dan dosen-dosen yang ahli dibidangnya seperti dosesn Tafsir tarbawi dan hadits tarbawi, perumusan langkah-langkahnya pertama standar mutu itu dibentuk berdasarkan analisis lingkungan, kedua pembentukan tim standar mutu dan melibatkan tim Gugus Penjamin Mutu (GPM), kaprodi bersama tim yang lainnya termasuk dosen yang ahli dibidang ahlinya, ketiga rapat persamaan presepsi, keempat perumusan dan penyusunan standar mutu, dan selanjutnya kalau sudah final dan melalui tahap beberapa revisi bisa diterapkan ke seluruh mahasiswa, dan hasil dari standarisasi mutu lulusan ada 4 buku yaitu: Buku pendamping mutu mahasiswa, Buku ekuivalen kurikulum FTIK, Buku pendamping mutu ujian komprehensif, dan Sistem Penjaminan Mutu Internal (SPMI).

Standar mutu kelulusan yang dibentuk untuk mengukur hasil kemampuan mahasiswa, ukuran yang digunakan sebagai dasar untuk membandingkan kuantitas, kualitas dengan perumusan standar mutu mahasiswa yang meliputi standar mutu akademik dan non akademik, diamana standar mutu itu dirumuskan dengan melibatkan semua objek yang ada dalam perguruan tinggi tersebut.

Temuan di atas diperkuat oleh Hari Sudradjad pendidikan yang bermutu adalah Pendidikan yang 
mampu menghasilkan lulusan yang memiliki kemampuan atau kompotensi, baik kompetensi akademik maupun kompetensi kejuruan, yang dilandasi oleh kompetensi personal dan sosial, serta nilai-nilai akhlak mulia, yang keseluruhannya merupakankecakapan hidup (life skill), pendidikan yang mampu menghasilkan manusia seutuhnya (manusia paripurna) atau manusia dengan pribadi yang integral (integrated personality) mereka yang mampu mengintegralkan iman, ilmu, dan amal. ${ }^{29}$

Teori diatas diperkuat oleh teori Nanang Fattah yang mengemukakan bahwa Perguruan tinggi memiliki standar mutu kelulusan yang dibentuk untuk mengukur hasil kemampuan mahasiswa. Secara kelembagaan, Sistem Penjaminan Mutu diposisikan sebagai bagian dari keseluruhan fungsi manajemen Pendidikan mengemban tugas dan tanggung jawab dalam mengukur dan menilai pemenuhan standar mutu sebagaimana yang telah ditetapkan dalam kebijakan atau regulasi. Sistem penjaminan mutu dalam kegiatannya fokus terhadap peningkatan mutu secara berkelanjutan dengan cara mengukur dan menilai mutu sistem Pendidikan, kinerja institusi Pendidikan, dan mutu program studi. ${ }^{30}$

Perumusan standar mutu yang dibentuk untuk mahasiswa ada tim dan dirumuskan bersama-sama Gugus Kendali Mutu tingkat fakultas FTIK, Gugus Kendali Mutu tingkat prodi FTIK

29 Hari Suderadjat, Manajemen Peningkatan Mutu Berbasis Sekolah; Peningkatan Mutu Pendidikan Melalui Implementasi KBK, (Bandung: Cipta Lekas Garafika, 2005), 17.

30 Nanang Fattah, Sistem Penjaminan Mutu Pendidikan, (Bandung: Remaja Rosdakarya, 2013), 3. dan dosen-dosen yang ahli dibidangnya seperti dosesn Tafsir tarbawi dan hadits tarbawi, langkahlangkah standar mutu itu dibentuk berdasarkan analisis lingkungan, kedua pembentukan tim standar mutu dan melibatkan tim Gugus Penjamin Mutu (GPM), kaprodi bersama tim yang lainnya termasuk dosen yang ahli dibidang ahlinya, Rapat persamaan presepsi, keempat perumusan dan penyusunan standar mutu, dan setelah melalui tahap beberapa revisi bisa diterapkan ke seluruh mahasiswa.

\section{Implementasi Standarisasi Mutu Lulusan FTIK}

Implementasi standarisasi mutu lulusan pada mahasiswa program studi PAI sebagai calon guru professional implementasinya di dalam buku tersebut terdapat tagihan mutu, yang meliputi: tagihan hafalan surat-surat pendek juz 30, hafalan ayat-ayat tarbawi/kependidikan, dan hafalan tentang hadits tarbawi. Kendala implementasi standarisasi mutu yaitu: Pertama, adanya seleksi masuk melalui SPAN menyebabkan banyak mahasiswa yang kesulitan dalam kemampuan baca tulis Al-qur'an serta pemahaman keagamannya kurang, karena hanya didasarkan pada nilai rapot. Kedua standarisasi proses perkuliahan untuk dosen di era pandemi seperti ini yang awalnya tatap muka berubah langsung menjadi daring akhirnya dibuatkan bersama tim gugus mutu fakultas standar penggunaan learning management sistem (LMS) agar proses pembelajaran menjadi seragam.

Dengan demikian, kendala pertama implementasi standarisasi mutu lulusan pada mahasiswa program studi PAI sebagai calon guru profesional adalah seleksi SPAN yang masuknya dari nilai raport dan kurang 
mengasai kemampuan BTQ dan tingkat pemahaman agamanya rendah dipetakan antara mahasiswa yang mampu dengan yang tidak baca tulis Al-qur'an, kemudian diserahkan catatan tersebut kepada DPA agar dibina, itu juga termasuk standarisasi mutu di FTIK.

Kendala kedua bahwa standarisasi proses perkuliahan untuk dosen di era pandemi banyak kebingungan akan proses kegiatan pembelajaran, setelah learning management sistem (LMS) khusus dosen-dosen di FTIK agar seragam dan terteta dengan baik proses yang ada di kampus khusunya dalam proses pembelajaran

Teori diatas diperkuat oleh Putu Subawa menyatakan bahwa Standarisasi adalah menentukan ukuran yang harus diikuti saat memproduksi produk tertentu, dan untuk menghasilkan produk yang akan diproduksi dalam berbagai ukuran merupakan tugas yang disederhanakan. Standardisasi adalah proses penetapan standar teknis, yang dapat berupa spesifikasi standar, standar metode pengujian, standar definisi, prosedur standar atau praktik. $^{31}$

Implementasi standar mutu ditetapkan sebagai tolak ukur penilaian untuk menentukan dan mencerminkan mutu penyelenggaraan akademik. Oleh karena itu, penetapan Sistem Penjaminan Mutu Internal mengacu pada standar mutu yang ditetapkan dengan mengikuti Standar Nasional Perguruan Tinggi (SNPT). Standar mutu ditetapkan untuk masing-masing strata pendidikan dengan mengadopsi atau memodifikasi

31 Putu Subawa, "Standarisasi Dunia Pendidikan", Jurnal Penjaminan Mutu Vol 02 No 02, 2016, 3 dari Standar Nasional Pendidikan Tinggi (SNPT), Badan Akreditasi Nasional Perguruan Tinggi (BAN-PT) dan standar tambahan yang berlaku di tingkat regional dan internasional. ${ }^{32}$

Teori di atas juga diperkuat oleh Rudi Suardi yang menyatakan bahwa mutu merupakan tingkat karakteristik yang melekat pada produk yang mencukupi persyaratan. Maksud derajat berarti selalu ada peningkatan setiap saat. Sedangkan karakteristik berarti hal-hal yang dimiliki produk, yang terdiri dari karakteristik fisik, karakteristik perilaku dan karakteristik sensori. ${ }^{33}$

\section{Ketercapaian Standar Mutu Lulusan FTIK}

Ketercapaian standar mutu lulusan pada mahasiswa PAI sebagai calon guru professional yaitu nilai IPK kalau kaitannya dengan akademik dan ketercapaian proses kuliah, Magang 2 keterkaitannya dengan penilaian di lapangan, Kaitannya sudah alumini yaitu berapa alumni yang diserap oleh masyarakat. Evaluasi melalui survei kepuasan berdasarkan angket input ke google from yang nantinya akan di share ke mahasiswa.

Ketercapaian standar mutu lulusan pada mahasiswa PAI sebagai calon guru professional yaitu nilai IPK kalau kaitannya dengan akademik dan ketercapaian proses kuliah, Magang 2 keterkaitannya dengan penilaian di lapangan, Kaitannya sudah alumini yaitu berapa alumni yang diserap oleh masyarakat. Evaluasi melalui survei kepuasan berdasarkan angket input ke

32 UIN Syarif Hidayatullah Jakarta, Standar Mutu Sistem Penjaminan Mutu Internal (SPMI), (Jakarta: CeQda), 7.

33 Rudi Suardi, Sistem Manajemen Mutu ISO 9000:2000 Penerapannya Untuk Mencapai TQM, (Jakarta: PPM, 2004), 3. 
google from yang nantinya akan di share ke mahasiswa.

Temuan di atas diperkuat oleh Mulyasa yang menyatakan bahwa lulusan sebagai output sekolah merupakan bagian dari sistem dalam manajemen mutu Pendidikan. mutu lulusan tidak dapat dipisahkan dari contect, input, proses, output dan outcome. Untuk itu, mutu lulusan yang sesuai dengan keinginan pelanggan Pendidikan adalah output yang mempunyai kriteria sebagai outcome yaitu dapat melanjutkan ke sekolah yang lebih tinggi dan siap untuk bekerja. Atau bisa dikatakan lulusan yang sesuai dengan Standar Kompetensi Lulusan (SKL) satuan Pendidikan, yaitu kualifikasi kemampuan lulusan yang mencakup pengetahuan, keterampilan, dan sikap, yang digunakan sebagai pedoman penilaian dalam penentuan kelulusan peserta didik dari satuan Pendidikan. SKL pada jenjang Pendidikan bertujuan untuk meningkatkan kecerdasan, pengetahuan, kepribadian, akhlak mulia, serta keterampilan untuk hidup mandiri dan mengikuti Pendidikan lebih lanjut. ${ }^{34}$

Berdasarkan paparan data dan analisisnya di atas, maka dapat dikatakan bahwa ketercapaian standar mutu lulusan pada mahasiswa PAI sebagai calon guru professional yaitu nilai IPK kaitannya dengan akademik dan ketercapaian proses kuliah, Magang 2 dengan penilaian di lapangan, lulusan yaitu berapa alumni yang diserap oleh masyarakat. Evaluasi melalui survei kepuasan berdasarkan angket input ke google from yang nantinya akan di share ke mahasiswa.

34 Mulyasa, Kurikulum Tingkat Satuan Pendidikan (Bandung: Remaja Rosdakarya, 2012), 91.

\section{KESIMPULAN}

Standarisasi mutu lulusan pada mahasiswa PAI sebagai calon guru professional menghasilkan Buku pendamping mutu mahasiswa, didalam buku tersebut terdapat tagihan tagihan, yang pertama tagihan hafalan surat-surat pendek juz 30, hafalan ayat-ayat tarbawi/kependidikan, yang ketiga hafalan tentang hadits tarbawi, . Buku ekuivalen kurikulum FTIK, , Buku pendamping mutu ujian komprehensif isinya tentang komprehensif, SPMI tersebut ada 4 Jenis dokumen di dalamnya: (1) Dokumen Kebijakan Mutu, (2) Dokumen Manual Mutu, (3) Dokumen Standar Mutu. (4) Dokumen Formulir Mutu.

Standar mutu lulusan dirumuskan secara bersama-sama antara Gugus Penjaminan Mutu tingkat fakultas, beserta Gugus Kendali Mutu tingkat prodi, dan dosen-dosen yang ahli di bidangnya seperti dosen Tafsir Tarbawi dan dosen Hadits Tarbawi, dengan beberapa langkah-langkahnya pertama standar mutu itu dibentuk berdasarkan analisis lingkungan, kedua pembentukan tim standar mutu dan melibatkan tim Gugus Penjamin Mutu (GPM), Kaprodi bersama tim yang lainnya termasuk dosen yang ahli dibidang ahlinya, ketiga rapat persamaan presepsi, keempat perumusan dan penyusunan standar mutu, dan selanjutnya kalau sudah final dan melalui tahap beberapa revisi bisa diterapkan ke seluruh mahasiswa, dan hasil dari standarisasi mutu lulusan ada 4 buku yaitu: Buku Pendamping Mutu Mahasiswa, Buku Ekuivalen Kurikulum, Buku Pendamping Mutu Ujian Komprehensif, dan Sistem Penjaminan Mutu Internal (SPMI). 
Implementasi standar mutu lulusan diantaranya melalui tagihantagihan mutu yang harus dikuasai oleh mahasiswa yaitu tagihan hafalan suratsurat juz 30, hafalan ayat-ayat tarbawi, dan hafalan hadis-hadis tarbawi. Kendala implementasi yang ditemui yaitu dengan adanya sistem SPAN dalam proses seleksi mahasiswa yang hanya didasarkan nilai raport menyebabkan pemetaan kemampuan BTQ dan pemahaman keagamaan masih kurang jelas.

\section{DAFTAR PUSTAKA}

Anggota IKAPI, Undang-Undang No. 14 tahun 2005 tentang Guru dan Dosen, Bab 1, Pasal 1, Ayat 1, (Bandung: Fokusmedia, 2011), 2

Baiq Rohiyatun, Menik Aryani, "Peran Ketua Program Studi Dalam Membentuk Kepemimpinan Karakter Melalui Kegiatan Himpunan Mahasiswa Program Studi (HMPS)", Jurnal Ilmu Sosial dan Pendidikan Vol.4 No. 4, 2020.

Fattah, Nanang. Sistem Penjaminan Mutu Pendidikan. Bandung: Remaja Rosdakarya. 2013.

Fauzi, Imron. Etika Profesi Keguruan. Jember: IAIN Jember Press, 2019

Getteng, Abd. Rahman, Menuju Guru Profesional dan Beretika, Yogyakarta: Grha Guru, 2012.

Hartaji, Motiva berprestasi pada mahasiswa. Depok:

Gunadarmapers, 2012.

Hubberman, Miles Saldana Qualitative Data Analysis, A Methods Sourcebook, Edition 3 USA:Sage Publications, 2014. Terjemahan Tjetjep Rohindi Rohidi, UI-Pre.

Khairun, Deasy Yunika, Ibrahim Al Hakim, "Analisis Asesmen Kebutuhan Mahasiswa Terhadap
Layanan Dosen Pembimbing Akademik", Jurnal Indonesia Konseling Pendidikan, Vol. 2 No. 2, 2018.

Moleong Lexy J., Metodelogi Penelitian Kualitatif, Bandung: PT Remaja Rosdakarya, 2017.

Mulyasa, Kurikulum Tingkat Satuan Pendidikan. Bandung: Remaja Rosdakarya. 2012.

Mundir, Metode Penelitian Kualitatif dan Kuantitatif, Jember, STAIN Jember Press, 2013.

Nur Kholis, Pendidikan Dalam Upaya Memajukan Teknologi, Jurnal Kependidikan, Vol. 1 No. 1.

Oemar Hamalik, Pendidikan Guru Berdasarkan Pendekatan Kompetensi, Jakarta: PT Bumi Aksara,2007.

Putu Subawa, Standarisasi Dunia Pendidikan, Jurnal Penjaminan Mutu Vol 02 No 02, 2016.

Soemanto Wasty, Psikologi Pendidikan, Jakarta: PT. Rhineka Cipta, 2006.

Suardi, Rudi. Sistem Manajemen Mutu ISO 9000:2000 Penerapannya Untuk Mencapai TQM. Jakarta: PPM. 2004.

Subawa, Putu. Standarisasi Dunia Pendidikan, Jurnal Penjaminan Mutu 02, no. 02. 2016.

Suderadjat, Hari. Manajemen Peningkatan Mutu Berbasis Sekolah; Peningkatan Mutu Pendidikan Melalui Implementasi KBK. Bandung: Cipta Lekas Garafika. 2005.

Sugiyono, Metode Penelitian Pendidikan, Bandung: Alfabeta, 2013.

Sugiyono. 2017. Metode Penelitian Kuantitatif, Kualitatif dan R\&D. Bandung: Alfabeta.

Sumiatini, Peran Guru Kelas Dalam Meningkatkan Motivasi Belajar 
Siswa, Jurnal Tarbawi, Vol. 3 N0. $02,2016$.

Sutrisno Edy, Manajemen Sumber Daya Manusia, Jakarta: Kencana, 2009.

Syahid Abdullah, Penerapan Pembelajaran Pendidikan Agama Islam Dalam Membentuk Karakter Pribadi yang Islami, Jurnal Edumaspul, Vol. 2 N0. 1, 2018.

UIN Syarif Hidayatullah Jakarta, Standar Mutu Sistem Penjaminan Mutu Internal (SPMI), (Jakarta: CeQda).

Universitas Islam Negeri KH. Achmad Siddiq Jember, "Buku Panduan PPL" 11 Juni 2021

Universitas Sriwijaya, Standar Mutu, Ogan Ilir: UPM Usri.

Uno, Hamzah B. Profesi Kependidikan: Problema, Solusi, dan Reformasi Pendidikan di Indonesi. Jakarta: PT Bumi Aksara. 2009.

Usman Husaini, Manajemen Teori, praktik, riset pendidikan, Jakarta: Bumi Aksara, 2009.

Uyoh, Sadulloh. Pedagogik (Ilmu Mendidik), Bandung: Alfabeta, 2010.

Wagiran, Kesiapan Mahasiswa Dalam Implementasi Pembelajaran Aktif Kontruktif, Jurnal Kependidikan, Vol. 35, No. 1.
Winarsih Sri, Kebijakan dan Implementasi Manajemen Pendidikan Tinggi dalam Meningkatkan Mutu Pendidikan, Cendekia, Vol. 15 No. 1, 2017. 